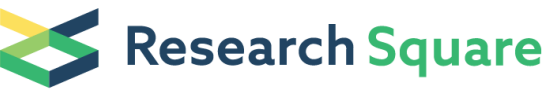 \\ Preprints are preliminary reports that have not undergone peer review. \\ They should not be considered conclusive, used to inform clinical practice, or referenced by the media as validated information.
}

\section{Hydroxytyrosol Effectively Improves The Quality of Pig Sperm at $17^{\circ} \mathrm{C}$}

\section{Dong Li}

Northwest Agriculture University: Northwest Agriculture and Forestry University

\section{Wenyu Zhang}

Northwest A\&F University: Northwest Agriculture and Forestry University

\section{Xuekai Tian}

Northwest A\&F University: Northwest Agriculture and Forestry University

\section{Zitong Xiao}

Northwest A\&F University: Northwest Agriculture and Forestry University

\section{Xin Zhao}

Northwest A\&F University: Northwest Agriculture and Forestry University

\section{Yulin He}

Northwest A\&F University: Northwest Agriculture and Forestry University

\section{Renrang Du}

Northwest A\&F University: Northwest Agriculture and Forestry University

\section{Gongshe Yang}

Northwest A\&F University: Northwest Agriculture and Forestry University

Taiyong Yu ( $\nabla$ yutaiyong310@nwsuaf.edu.cn )

Northwest Agriculture and Forestry University

\section{Research}

Keywords: hydroxytyrosol, sperm preservation, artificial insemination, pig

Posted Date: January 28th, 2021

DOI: https://doi.org/10.21203/rs.3.rs-152596/v1

License: (c) (1) This work is licensed under a Creative Commons Attribution 4.0 International License.

Read Full License

Version of Record: A version of this preprint was published at Theriogenology on January $1 \mathrm{st}, 2022$. See the published version at https://doi.org/10.1016/j.theriogenology.2021.10.018. 


\section{Abstract}

Background: Artificial insemination technology is the production technology used in more than $99 \%$ of the world's pig farms. As the frozen sperm damage is very serious, the preservation of pig sperm is mainly carried out at $17^{\circ} \mathrm{C}$. However, the accumulation of a large amount of reactive oxygen species (ROS) during the preservation process is the main reason for the deterioration of sperm quality. In our research, by adding different concentrations of hydroxytyrosol to the diluent during the storage of pig sperm at $17^{\circ} \mathrm{C}$, we compared them with the traditional diluent to study the cumulative amount of ROS, the extent of membrane damage, the sperm acrosome integrity, the activity of antioxidant enzymes, and other indicators to evaluate the effect of hydroxytyrosol on the changes of active oxygen species and sperm quality during storage. After we determined the optimal amount of hydroxytyrosol in the diluent, proteomics was used to monitor difference in sperm protein expression between the control group and the addition of $120 \mu \mathrm{mol} / \mathrm{L}$ hydroxytyrosol group (optimum concentration). Ultimately, we selected the control group and the $120 \mu \mathrm{mol} / \mathrm{L}$ hydroxytyrosol group to test the effect of artificial insemination.

Results: The results of our research showed that during storage of pig sperm at $17{ }^{\circ} \mathrm{C}$, the sperm quality and antioxidant capacity of the hydroxytyrosol-treated group were significantly improved $(P<0.05)$. Proteomics sequencing analysis proved that the addition of hydroxytyrosol treatment group has potential value in improving sperm quality. Besides, the significant increase in sow pregnancy rate and piglet birth weight also confirmed that sperm quality during storage can be of vital importance in actual production $(P<0.05)$.

Conclusions: Based on our results, we demonstrate that the addition of hydroxytyrosol to the diluent can improve the quality of pig sperm and the efficiency of artificial insemination.

\section{Background}

Pig artificial insemination (Al) has been widely used in recent years, and the sperm storage at $17^{\circ} \mathrm{C}$ has important significance in commercial production $[8,22]$. Pig sperm is extremely sensitive to temperature changes especially low temperature $[15,32]$. The cold shock caused by low temperature has a serious impact on sperm quality and the fertilization potential of sperm [13, 25, 31]. Besides, high level of technology and equipment are required for cryopreservation of pig sperm. Hence, it is very important to study the pig sperm preserved at $17^{\circ} \mathrm{C}$ in research and production. [14, 29]. However, during the sperm preservation, sperm suffers from severe oxidative stress due to the accumulation of ROS which could decrease the sperm quality, compromise to the plasma membrane, the acrosome, the DNA integrity and the protein $[12,24,28]$. Besides, sperm with too high DNA fragment may even bring genetic disease to the offspring through sperm [20]. The key to solve the problem of ROS accumulation during pig sperm preservation is the formulation of the diluent [7].

In recent years, natural antioxidants are being largely investigated owing to their outstanding antioxidant capacity [6]. Hydroxytyrosol $(\mathrm{HT})$ is a natural active oxygen scavenger known as ROS scavenger and 
many studies have reported that HT can effectively decrease the accumulation of ROS in various cells [23]. For instance, HT can protect vascular endothelial cells from the cytotoxic effects of hydrogen peroxide [33]. To the present, the reports of HT in sperm are only in the cryopreservation of ram sperm [3, 19] and human sperm antioxidant capacity [16]. There is still no research to evaluate the effect of HT in the preservation of pig sperm at $17^{\circ} \mathrm{C}$. Due to the great antioxidant effect of $\mathrm{HT}$, we conjectured that adding $\mathrm{HT}$ to pig sperm diluent might improve sperm quality [5]. The objective of our study was to evaluate the effects of different concentrations of $\mathrm{HT}$ to sperm extender and assess the potential value of $\mathrm{HT}$ in the preservation of sperm at $17^{\circ} \mathrm{C}$. Our results showed that $\mathrm{HT}$ could significantly improve the quality of pig sperm during storage at $17^{\circ} \mathrm{C}$ which also has potential application value in production.

\section{Materials And Methods Chemicals and sources}

Unless otherwise stated, all chemicals used were purchased from Sigma Chemical Co. (St. Louis, MO, USA). The extender used in this study was Beltsville thawing solution (BTS) which was composed of $37.5 \mathrm{~g}$ fructose, $1.25 \mathrm{~g}$ of ethylenediaminetetraacetic acid (EDTA)-Na2, $6.0 \mathrm{~g}$ sodium citrate, $6.0 \mathrm{~g}$ of citric acid two sodium, $0.75 \mathrm{~g}$ of potassium chloride, $1.25 \mathrm{~g}$ of $\mathrm{NaHCO}_{3}$ and $0.2 \mathrm{mg}$ of gentamicin in $1000 \mathrm{~mL}$ of deionized water. The only difference between control group and treatment group is the addition of HT. Samples of control and treatment group repeated at least five times.

\section{Sperm collection}

We selected 6 healthy Large White Pigs from the national core conservation farms in Xingping City, Shaanxi Province, China $\left(34^{\circ} 12^{\prime} \mathrm{N}, 108^{\circ} 17^{\prime} \mathrm{E}\right)$. The pigs were in the same housing and management conditions, the environment was controlled at $15-25^{\circ} \mathrm{C}$, individual fences in the building, the windows were exposed to natural daylight and supplemental light, a total of 16 hours of light per day (at the pig eye level $\geq 150$ lx light intensity). According to the breeding standards of adult Al pigs, they could get water freely and fed commercial forage. A total of 30 samples were collected (collect 6 samples from different pigs each time, every week and a total of five times), the first pre-sperm fraction was not collected and the gelatinous portion was discarded. The test was carried out by hand-collecting, and the sperm was collected and filtered twice with $0.22 \mu \mathrm{m}$ filter membrane. The sperm motility was detected by computer-assisted sperm analysis CASA system (Hamilton Thorne Research, Beverly, MA, 87 USA). The test used only sperm samples with ejaculation volume $\geq 200 \mathrm{ml}$, milky white, and slightly smelly, with vitality $>85 \%$. We use BTS to dilute sperm to adjust the concentration to approximately $3 \times 10^{8} \mathrm{sperm} / \mathrm{ml}$ [11]. Various concentrations of $H T(0,40,80,120,160,200 \mu \mathrm{mol} / \mathrm{L})$ were added to the sperm dilution.

\section{Sperm motility assay}


The sperm motility of each preservation group was tested using the CASA system and measured at 0,1 , $2,3,4,5$ days. The method was as follows: $8 \mu \mathrm{L}$ of each group sample was pre-warmed on a clean slide and then to be observed at $37^{\circ} \mathrm{C}$. The CASA system automatically detected the sperm motility in the field of view (We selected five randomly fields for each sample and a minimum of 300 sperm cells were recorded for each view). Samples of control and treatment group repeated at least five times.

\section{Analysis of ROS content}

The ROS accumulation was measured at $0,1,3,5$ days during storage. $300 \mu \mathrm{L}$ of specimen was taken from each sperm sample. $10 \mu \mathrm{L}$ of the active oxygen fluorescent probe DCFH-DA was added and incubated at $37^{\circ} \mathrm{C}$ for 30 minutes. Flow cytometry was used to detect the fluorescence intensity of the probe (Nanjing Institute of Bioengineering, Co., Nanjing, China (Product No.: E004-1-1)). Samples of control and treatment group repeated at least five times.

\section{Analysis of plasma membrane and acrosome integrity}

The sperm membrane and acrosome integrity were measured at $0,1,3,5$ days during liquid preservation of sperm [9]. Sperm plasma: $0.1 \mu \mathrm{L}$ SYBR-14 working solution, $0.5 \mu \mathrm{L} \mathrm{PI} \mathrm{(propidium} \mathrm{iodide)} \mathrm{working}$ solution and $80 \mu \mathrm{L}$ sample heated in a $37^{\circ} \mathrm{C}$ water bath for 10 minutes. $10 \mu \mathrm{L}$ sample was placed on a clean glass slide and observed at $37^{\circ} \mathrm{C}$. Sperm acrosome: $0.1 \mu \mathrm{L}$ DAPI (4', 6-diamidino-2-phenylindole) working solution was pre-incubated with $80 \mu \mathrm{L}$ sample for 30 minutes at $37^{\circ} \mathrm{C}$ and $25 \mu \mathrm{L}$ sample smeared on the microslide. After fixation for 10 minutes in methanol, $5 \mu \mathrm{L}$ of fluorescein isothiocyanateconjugated peanut agglutinin (FITC-PNA) working solution was stained. After incubating for 20 minutes at $37^{\circ} \mathrm{C}$, the slide was observed at $37^{\circ} \mathrm{C}$. Each view was not less than 300 sperm. The sperm plasma membrane and the acrosome integrity were detected using an inverted fluorescence microscope (Leica DMI8). The regression equation was obtained by least squares analysis. Image Pro-Plus software was used to quantify fluorescence intensity (v6.0). Samples of control and treatment group repeated at least five times.

\section{Pig sperm DNA damage test (Comet electrophoresis test)}

When the pig sperm was preserved to day 3, the DNA damage of the control group and the HT 120 $\mu \mathrm{mol} / \mathrm{L}$ group were observed by the comet assay. The test method was carried out according to the instruction of the DNA Damage Detection Kit (Nanjing Institute of Bioengineering, Co., Nanjing, China (Product No.: G010 -1-1)). Samples of control and the HT $120 \mu \mathrm{mol} / \mathrm{L}$ group repeated at least five times.

\section{Analysis of sperm antioxidant ability}


The Catalase (CAT) and Total antioxidant capacity (T-AOC) were determined using kits according to the manufacturer's instruction (Nanjing Institute of Bioengineering, Co., Nanjing, China (Product No.: A007-11, A015-1-2)). The preparation of sample followed the instructions of the operation. The CAT activity was measured at $405 \mathrm{~nm}$ and T-AOC was measured at $520 \mathrm{~nm}$ in the fluorescent microplate reader (Boster, Co., USA). Samples of control and treatment group repeated at least five times.

Superoxide Dismutase (SOD) and Glutathione Peroxidase (GSH-PX) analysis in this study were performed according to the manufacturer's instruction (Nanjing Institute of Bioengineering, Co., Nanjing, China (Product No.: A001-3-2, A005-1-2). Samples were measured at $550 \mathrm{~nm}$ for SOD and $412 \mathrm{~nm}$ for GSH-PX in the fluorescent microplate reader (Boster, Co., USA). Samples of control and treatment group repeated at least five times.

The Malondialdehyde (MDA) content was assessed using assay kit (thiobarbituric acid (TBA) method) (Nanjing Institute of Bioengineering, Co., Nanjing, China (Product No.: A003-1-2)) according to the manufacturer's instruction. The result was measured at $532 \mathrm{~nm}$ in the fluorescent microplate reader (Boster, Co., USA). Samples of control and treatment group repeated at least five times.

\section{Sequencing analysis of pig sperm protein group}

Protein sample was sonicated three times on ice using a high intensity ultrasonic processor (Scientz) in lysis buffer ( $8 \mathrm{M}$ urea, $1 \%$ Protease Inhibitor Cocktail). The remaining debris was removed by centrifugation at $12,000 \mathrm{~g}$ at $4^{\circ} \mathrm{C}$ for 10 minutes. Ultimately, the supernatant was collected and the protein concentration was determined with BCA kit according to the manufacturer's instructions.

\section{Trypsin digestion:}

For digestion, the protein solution was reduced with $5 \mathrm{mM}$ dithiothreitol for $30 \mathrm{~min}$ at $56^{\circ} \mathrm{C}$ and alkylated with $11 \mathrm{mM}$ iodoacetamide for $15 \mathrm{~min}$ at $17^{\circ} \mathrm{C}$ in darkness. The protein sample was then diluted by adding $100 \mathrm{mM}$ TEAB to urea concentration less than $2 \mathrm{M}$. Finally, trypsin was added at 1:50 trypsin-toprotein mass ratio for the first digestion overnight and 1:100 trypsin-to-protein mass ratios for a second 4 h-digestion.

\section{TMT labeling:}

After trypsin digestion, peptide was desalted by Strata XC18SPE column (Phenomenex) and vacuumdried. Peptide was reconstituted in 0.5 M TEAB and processed according to the manufacturer's protocol for TMT kit/iTRAQ kit. Briefly, one unit of TMT/iTRAQ reagent was thawed and reconstituted in acetonitrile. The peptide mixtures were then incubated for 2 hours at $17{ }^{\circ} \mathrm{C}$ and pooled, desalted and dried by vacuum centrifugation. 


\section{HPLC fractionation:}

The tryptic peptides were fractionated into fractions by high $\mathrm{pH}$ reverse-phase HPLC using Agilent 300Extend C18 column ( $5 \mu \mathrm{m}$ particles, $4.6 \mathrm{~mm}$ ID, and $250 \mathrm{~mm}$ length). Briefly, peptides were first separated with a gradient of $8 \%$ to $32 \%$ acetonitrile $(\mathrm{pH} 9.0)$ over 60 min into 60 fractions. Then, the peptides were combined into 18 fractions and dried by vacuum centrifuging.

\section{LC-MS/MS analysis:}

The tryptic peptides were dissolved in $0.1 \%$ formic acid (solvent $A$ ), directly loaded onto a home-made reversed-phase analytical column (15-cm length, $75 \mu \mathrm{m}$ i.d.). The gradient was comprised of an increase from $6 \%$ to $23 \%$ solvent B ( $0.1 \%$ formic acid in $98 \%$ acetonitrile) over $26 \mathrm{~min}, 23 \%$ to $35 \%$ in $8 \mathrm{~min}$ and climbing to $80 \%$ in $3 \mathrm{~min}$ then holding at $80 \%$ for the last $3 \mathrm{~min}$, all at a constant flow rate of $400 \mathrm{~nL} / \mathrm{min}$ on an EASY-nLC 1000 UPLC system.

The peptides were subjected to NSI source followed by tandem mass spectrometry (MS/MS) in Q Exactive $^{T M}$ Plus (Thermo) coupled online to the UPLC. The electrospray voltage applied was $2.0 \mathrm{kV}$. The $\mathrm{m} / \mathrm{z}$ scan range was 350 to 1800 for full scan, and intact peptides were detected in the Orbitrap at a resolution of 70,000. Peptides were then selected for MS/MS using NCE setting as 28 and the fragments were detected in the Orbitrap at a resolution of 17,500. A data-dependent procedure that alternated between one MS scan followed by $20 \mathrm{MS} / \mathrm{MS}$ scans with 15.0 s dynamic exclusion. Automatic gain control (AGC) was set at 5E4. Fixed first mass was set as $100 \mathrm{~m} / \mathrm{z}$.

\section{Database search:}

The resulting MS/MS data were processed using the Maxquant search engine (v.1.5.2.8). Tandem mass spectra were searched against databases concatenated with the reverse decoy database. Trypsin/P was specified as a cleavage enzyme allowing up to 2 missing cleavages. The mass tolerance for precursor ions was set as $20 \mathrm{ppm}$ in the First search and $5 \mathrm{ppm}$ in the Main search, and the mass tolerance for fragment ions was set as $0.02 \mathrm{Da}$. Carbamidomethyl on Cys was specified as fixed modification and oxidation on Met was specified as variable modifications. FDR was adjusted to $<1 \%$ and the minimum score for peptides were set $>40$.

\section{Statistics}

We use three statistical analysis methods, namely, principal component analysis (PCA), relative standard deviation (RSD) and Pearson's Correlation Coefficient, so that we could evaluate the quantitative repeatability of protein (Supplement Figure1. a, b, c). 
We perform statistics on the distribution of differentially expressed proteins in GO secondary annotations. GO annotations are divided into three major categories: Biological Process, Cellular Component and Molecular Function, which explain the biological role of proteins from different perspectives. Then, we used software to perform subcellular structure localization prediction and classification statistics for differentially expressed proteins (Figure4. d; Supplement Figure2. c. d).

\section{Artificial insemination test}

In order to study the reproductive effect of the control group and the HT $120 \mu \mathrm{mol} / \mathrm{L}$ group after 3 days of storage. We chose 198 healthy Large White multiparous sows and only a small difference in body weight (99 Large White sows in the control group and treatment group). The experimental animals were selected from the Huayang breeding farm in Luonan County, Shaanxi Province, China ( $33^{\circ} 52^{\prime} \mathrm{N}, 109^{\circ} 44^{\prime} \mathrm{E}$ ). All sows are in the same management environment, and the sows were fed and managed according to commercial standards before and after artificial insemination.

Artificial insemination was performed by skilled technicians in accordance with standardized artificial insemination procedures and each sow insemination with 40 to $50 \mathrm{ml}$ sperm (the sperm concentration of sperm doses are approximately $3.0 \times 10^{8} \mathrm{sperm} / \mathrm{ml}$, ensure that at least 3 billion active sperm). The sows were fertilized in the morning and fertilized again after 12 hours (completing all works within 10 days).

After 35 days of artificial insemination, the hand-held ultrasonic detector was used to check the pregnancy status of all sows (Guangzhou sonostar V6, China). When the piglets were born, we recorded the following data: Laying births, Live number, Live rate, Healthy number, Health rate, Primary weight.

\section{Statistical analysis}

All results were expressed as the mean \pm SD. Sperm activity, plasma membrane integrity, acrosome integrity, T-AOC activity, MDA content, CAT activity, ROS accumulation, SOD content and GSH-PX activity were compared using Duncan's multiple-range test. Statistical analyses were performed using Statistical Product and Service Solutions (SPSS 21; SPSS, Chicago, IL, USA). Statistically significant differences between variable were determined at $P<0.05$.

\section{Results}

\section{Hydroxytyrosol improves the preservation of pig sperm at $17^{\circ} \mathrm{C}$}

From the second day of sperm preservation, the sperm motility of the treatment groups were significantly higher than the control group (Figure1.a, $P<0.05$ ). The sperm motility of the treated group with 120 $\mu \mathrm{mol} / \mathrm{L} \mathrm{HT}$ added to the sperm diluent was significantly higher than the control group when it was stored 
to day $3(P<0.01)$. When the sperm motility of the control group decreased to $59.48 \%$ on day 3 , the sperm motility of the group with $120 \mu \mathrm{mol} / \mathrm{L} \mathrm{HT}$ was still maintained at $70.20 \%$. The sperm motility of control group was below $40 \%$ when stored to day 5 , but the sperm motility of the group with $120 \mu \mathrm{mol} / \mathrm{L}$ HT was still $48.00 \%$ which was significantly higher $(P<0.01)$. The addition of HT to the diluent improved the quality of sperm during the state of preservation and the addition of $120 \mu \mathrm{mol} / \mathrm{L} \mathrm{HT}$ to the diluent greatly improved the sperm motility during sperm preservation.

From day 3 , the mean fluorescence intensity (MFI) of different concentrations of HT's (2',7'Dichlorofluorescein, DCF) significantly lower than the control group (Table1, $P<0.05$ ), while the MFI of the $120 \mu \mathrm{mol} / \mathrm{L} \mathrm{HT}$ addition group significantly lower than the other groups $(P<0.05)$. When the pig sperm preserved at day 5 , the ROS of each group increased rapidly, and the overall peak of the DCF fluorescence peak shifted to the right (Figure1.b). The average MFI of the control group reached 7047, which is significantly higher than the groups adding HT $(P<0.01)$. Besides, the $120 \mu \mathrm{mol} / \mathrm{L} \mathrm{HT}$ group maintained at a low level compared with other groups (Table 1, $P<0.05$ ), which indicated that the addition of $120 \mu \mathrm{mol} / \mathrm{L} \mathrm{HT}$ group significantly reduced the accumulation of ROS during sperm preservation.

After the addition of $\mathrm{HT}$ to the diluent, the plasma membrane damage rate of the sperm is significantly decreased $(P<0.05)$, especially the sperm membrane with the $120 \mu \mathrm{mol} / \mathrm{L} \mathrm{HT}$ addition group. Besides, when the sperm was preserved to day 5 (Figure2.a), this group showed significant difference from other groups $(P<0.05)$. The acrosome integrity of each group decreased with longer sperm preservation time. However, there was no significant difference between all groups $(P>0.05)$. On the third day of preservation, although the acrosome integrity of groups added with HT were higher than the control group, the statistical difference was not significant $(P>0.05)$ (Figure2.c).

By observing the DNA damage of the control group and added $120 \mu \mathrm{mol} / \mathrm{L}$ HT group on the third day, we found that the fragmentation degree of the $120 \mu \mathrm{mol} / \mathrm{L} \mathrm{HT}$ group was lower than the control group (Figure2.e).

\section{Hydroxytyrosol slows the rate of decline in sperm antioxidant enzyme activity}

Throughout the preservation period, the total antioxidant capacity (T-AOC) of pig sperm gradually decreased with time passing by (Figure3.a). When stored on the day 1, the T-AOC of HT groups were significantly higher than the control group $(P<0.05)$. On the day 3 , there were two groups (HT 120 $\mu \mathrm{mol} / \mathrm{L}, 200 \mu \mathrm{mol} / \mathrm{L})$ significantly different from the control group $(P<0.05)$. Besides, the addition of 120 $\mu \mathrm{mol} / \mathrm{L} \mathrm{HT}$ continued to perform best in the 5 days of preservation, which was significantly superior to the other groups $(P<0.05)$.

Glutathione peroxidase (GSH-PX) activity decreased gradually with the prolonged sperm preservation (Figure3.b). On the day 3, the $120 \mu \mathrm{mol} / \mathrm{L}$ HT group showed significant difference from other groups $(P<$ 
0.05). When stored on the day 5, although the GSH-PX activity of each group decreased sharply, the enzyme activity in HT groups were still higher than the control group and the HT $120 \mu \mathrm{mol} / \mathrm{L}$ group was the best $(P<0.05)$.

From day 1 , the Superoxide dismutase (SOD) of the control group was at a lower level, while the HT groups showed a higher level (Figure3.c). Besides, the $120 \mu \mathrm{mol} / \mathrm{L} H \mathrm{HT}$ group showed a high value and significantly different compared with other groups $(P<0.05)$. Our result showed that groups added HT could effectively improve the activity of SOD during preservation.

The day 1 result showed the catalase (CAT) activity of the HT treatment groups were significantly higher than the control group (Figure3.d) $(P<0.05)$. Besides, treatment groups were significantly higher than the control group, indicating that $\mathrm{H}_{2} \mathrm{O}_{2}$ was accumulating. On the third day of preservation, the HT tested group showed significant difference compared with the control group $(P<0.05)$.

During the whole sperm preservation, the malondialdehyde (MDA) content increased during the storage time (Figure3.e). On the day 3, the malondialdehyde content (MDA) of treated groups were significantly lower than the control group $(P<0.05)$. When on day 5 , the MDA content increased sharply, and the pig sperm membranous system was severely damaged. However, the content of MDA in HT treatment groups were lower than the control group, the MDA content in the $120 \mu \mathrm{mol} / \mathrm{L} H \mathrm{HT}$ group was the lowest $(P<$ 0.05).

\section{Proteomics of the control group and $120 \mu \mathrm{mol} / \mathrm{L} \mathrm{HT}$ group showed significant differences}

In this experiment, a total of 259,816 secondary spectrums were obtained by mass spectrometry (Figure4. a). After the mass spectrum, secondary spectrum was searched by protein theory data. The available effective spectrum number was 33704 , and the spectrum utilization rate was $13.0 \%$. The spectral analysis identified a total of 17,615 peptides, with a specific peptide of 16513 . Our results showed that a total of 2832 proteins, 2483 proteins were quantifiable (quantitative proteins indicated at least one comparative group with quantitative information). The threshold of change was expressed by 1.3 times (Fold Change=1.3), and the t-test $P<0.05$ was used as the significant threshold. In the quantified proteins, the expression of 163 proteins in the HT/NC comparison group occurred up-regulation, and 45 proteins, down-regulate (Figure4. b).

Through database comparison and analysis, COG (Clusters of Orthologous Groups of proteins) / KOG functional classification statistics of differentially expressed proteins were performed (Figure4. e; Supplement Figure2. e. f). The results showed that the differences are mainly observed in the protein translation modification, normal cell function, and signal transduction. Besides, these differential proteins also played an important role in maintaining the cytoskeleton and normal physiological function. Through GO secondary annotations, our results showed that the addition of HT to the sperm diluent 
made the protein expression different in Biological Process, Cellular Component and Molecular Function (Figure4. c; Supplement Figure2. a. b).

We performed enrichment analysis on three levels of GO classification, KEGG pathway, and protein domain for differentially expressed proteins in each comparison group (Figure5; Supplement Figure 3; Supplement Figure4). The purpose was to discover whether differentially expressed proteins has significant enrichment trend in certain functional types. For the enrichment test (Fisher's exact test is used here), the $P$-value obtained by the bubble chart showed the functional classification and pathway of significant enrichment of differential proteins $(P<0.05)$. We performed differential protein enrichment analysis on the three major categories (Biological Process, Cellular Component, Molecular Function) in GO classification (Supplement Figure5). The results of the data showed that the protein difference between $120 \mu \mathrm{mol} / \mathrm{L} \mathrm{HT}$ group and the control group were mainly reflected in the direction of membrane lipid transport and energy metabolism. The results of KEGG analysis were not highly correlated in sperm motility, but the protein difference in cell metabolism was surprising. The enrichment performance of protein domains showed differences in cell energy supply and cell metabolism.

The biological process results showed that the differential proteins play an important role in regulating gene expression and maintaining the normal cell cycle (Figure6. b). The results of cellular components showed that proteins are differentially expressed in maintaining cell membrane structure and mitochondrial function (Figure6. c). In terms of molecular function, these differential proteins had a wide influence on the enzymes involved in the redox process, which was beneficial to maintain the normal function of cells (Figure6. d). The results of KEGG pathway indicated that the differential protein expression mainly affected the direction of disease, which also had a significant role in maintaining cellular pathways and normal metabolism (Figure6. e) $(P<0.05)$. The results of the protein domain showed that the differential proteins were mainly concentrated in cellular immunity and transport, which was also very important for improving the quality of sperm during storage (Figure6. f).

\section{The addition of hydroxytyrosol to sperm diluent has better production potential}

According to the results of artificial insemination in pigs (Table 2), the average pregnancy rate of the 120 $\mu \mathrm{mol} / \mathrm{L}$ HT group reaches $89.30 \%$, which was significantly higher than the control group of $76.70 \%(P<$ 0.01). Besides, $120 \mu \mathrm{mol} / \mathrm{L} \mathrm{HT}$ treatment group not only increased the pregnancy rate of the sows and the birth weight of the piglets, which also promoted the results of artificial insemination $(P<0.05)$.

\section{Discussion}

The concentration of ROS in pig sperm at $17^{\circ} \mathrm{C}$ accumulates over time, which is a major factor threatening the quality of pig sperm $[17,30]$. In our experiment, we found that the activity of pig sperm stored with HT were better than control group from the second day of storage and the $120 \mu \mathrm{mol} / \mathrm{L} \mathrm{HT}$ 
group was the best. As one of the prerequisites for maintaining sperm motility and sperm-related physiological activities, low-dose ROS could help to improve sperm capacitation and protein phosphorylation [2]. Therefore, high level of ROS could lead to male infertility and studies have demonstrated that antioxidants could reduce cellular ROS accumulation [21]. Our result showed the ROS concentration in sperm maintained at a lower level at the beginning of normal temperature storage, which was consistent with the results of Sutovsky's study [27]. However, the ROS concentration in sperm increased dramatically with longer storage. In addition, the quality of sperm and the membrane were also declining. Our result showed the rise of the ROS content of the sperm caused a higher oxidative stress state of the sperm, adding HT could relieve the accumulation tendency of the active oxygen and reduce the accumulation of active oxygen. Subsequently, by further detecting the damage of the plasma membrane and acrosome of the sperm during storage, we found that the plasma membrane suffered severe damage with longer storage, and the integrity of the plasma membrane decreased quickly in the later stage of preservation, which might be due to membrane lipid peroxidation causes by ROS accumulation $[4,25]$. The detection of membranous peroxidation marker MDA also showed a significant increase on the later stage of preservation which again confirmed our assumption. However, our result showed that the integrity and status of the pig sperm acrosome were not affected by the different concentrations of $\mathrm{HT}$ during the entire preservation. On the fifth day of storage, the DNA damage results showed that the control group's DNA was greatly fragmented and easily damaged, mainly because of the accumulation of ROS. Meanwhile, we conjecture this might cause oxidative damage to the sperm DNA, which was alleviated by the addition of $\mathrm{HT}$ [3].

The antioxidant enzyme system of mammalian sperm consists of the following enzymes: SOD, GSH-Px, glutathione reductase and catalase [10], and some low molecular weight antioxidants, such as Lglutathione. Glycopeptide (GSH), L-ergothione (ERT), L-ascorbic acid, which are designed to neutralize sperm production of harmful active substances including superoxide $\left(\mathrm{O}^{2-}\right)$, hydroxyl $(\cdot \mathrm{OH})$ and Hydrogen peroxide $\left(\mathrm{H}_{2} \mathrm{O}_{2}\right)$ [1]. At present, it is unclear whether $\mathrm{HT}$ could reduce the active oxygen content of sperm by directly neutralizing the active oxygen in the sperm or directly participating in the production of antioxidant enzymes. In the initial stage of sperm preservation, the antioxidant enzyme activity and the total antioxidant showed the best. The results showed that the activity of the antioxidant enzyme system decreased gradually. After adding $\mathrm{HT}$, the trend of the decrease in enzyme activity was delayed, and the state of the whole antioxidant enzyme system was improved. Especially, the addition of $120 \mu \mathrm{mol} / \mathrm{L} \mathrm{HT}$ improved the sperm quality as well as its ability to remove ROS. In addition, our result demonstrated that the HT works more prominently in the stage of sperm preservation.

The addition of HT to pig sperm dilutions greatly affected the expression of porcine sperm protein. From our results, we could see that the difference proteins between the treatment group and the control group were mainly concentrated in maintaining the cytoskeleton, normal physiologic functional, cell energy supply and cell metabolism. Our results showed that the protein of maintaining sperm normal ability was expressed after adding $\mathrm{HT}$, which was helpful to improve sperm comprehensive ability. Combined with our results, we found that HT could reduce the accumulation of ROS and promote the expression of 
proteins that improve sperm quality, which was of great value for normal temperature storage of pig sperm.

In the subsequent artificial insemination test, the pregnancy rate of the sow and the newborn litter weight of the piglets were significantly increased $(P<0.05)$. In actual production, the commonly used method of pig sperm storage is short-term preservation [18]. From our experimental results (Fig1.a), the quality of sperm after 3 days of storage dropped rapidly (sperm motility is less than $60 \%$ ). Therefore, based on the consideration of production value, we do not recommend using sperm stored at $17{ }^{\circ} \mathrm{C}$ for more than 3 days during production. Our experiment proved that adding HT could improve the effect of normal temperature preservation of pig sperm. At the same time, from the accumulation of ROS and the expression of protein, $\mathrm{HT}$ had a very good potential application value. Our artificial insemination experiment also confirmed this. Adding strong oxidants in the process of sperm preservation has an inestimable value for improving the quality of sperm. We hope this experiment can provide some reference for sperm preservation at room temperature

Taken together, our results showed that adding an appropriate amount of HT to the BTS extender has extraordinary consequence. In addition, HT has huge potential use value in artificial insemination.

\section{Conclusion}

One of the key problems to improve the preservation effect of pig sperm at $17^{\circ} \mathrm{C}$ is to solve the accumulation of ROS. The results we reported here have demonstrated that the quality of pig sperm could be effectively improved by adding appropriate concentration of HT into BTS diluent. In addition, adding HT in BTS diluent could effectively reduce the damage of oxidative free radicals on sperm, which played an important role in maintaining the normal physiological function of pig sperm. The results showed that the efficiency of artificial insemination was improved by adding appropriate amount of HT, which was of great significance in practical production. Furthermore, adding HT during the preservation of sperm at $17^{\circ} \mathrm{C}$ has a very high potential production value.

\section{Abbreviations}

Al: Artificial insemination; HT: hydroxytyrosol; ROS: reactive oxygen species.

\section{Declarations}

\section{Ethics approval and consent to participate}

The study was approved by the Institutional Animal Care and Use Committee of Northwest A\&F University (Yangling Shaanxi, China). All operations were carried out according to the university's guidelines for animal research.

\section{Consent for publication}


All of the authors have approved the final version of the manuscript, agree with this submission to Journal of Animal Science and Biotechnology.

\section{Availability of data and material}

All the data analysed during this study are included in this article and its supplementary information files.

\section{Competing interests}

The authors declare that they have no competing interests.

\section{Funding}

This study was supported by Key R \& D Program of Shaanxi (2017ZDXM-NY-077, 2018ZDXM-NY-02-05) and National Key R\&D Program of China囚2017YFD0502003).

\section{Authors' contributions}

Taiyong $\mathrm{Yu}$ is the leader of the project, conceived and designed the experiment. Dong Li and Wenyu Zhang performed experiments, analyzed data and wrote the manuscript. Xuekai Tian, Yulin He, Zitong Xiao and Xin Zhao contributed to the manuscript preparation. Renrang Du and Gongshe Yang contributed to the revisions. All authors reviewed and approved the final manuscript.

\section{Acknowledgements}

We would like to thank Ms. Fan Ling for correcting the language of this article, and your patient modification has made the content of the article enjoyable.

\section{Authors' information (optional)}

${ }^{1}$ Key Laboratory of Animal Gennetics, Breeding and Reproducation of Shaanxi Province, Laboratory of Animal Fat Deposition \& Muscle Development, College of Animal Science and Technology, Northwest A\&F University, Yangling Shaanxi 712100, China

\section{References}

1. Aitken RJ. Free radicals, lipid peroxidation and sperm function. Reprod Fertil Dev. 1995;7:659-68.

2. Aitken RJ. Reactive oxygen species as mediators of sperm capacitation and pathological damage. Mol Reprod Dev. 2017;84:1039-52.

3. Arando A, Delgado JV, Fernandez-Prior A, Leon JM, Bermudez-Oria A, Nogales S, Perez-Marin CC. Effect of different olive oil-derived antioxidants (hydroxytyrosol and 3,4-dihydroxyphenylglycol) on the quality of frozen-thawed ram sperm. Cryobiology. 2019;86:33-9.

4. Arimon M, Takeda S, Post KL, Svirsky S, Hyman BT. Berezovska, O. Oxidative stress and lipid peroxidation are upstream of amyloid pathology. Neurobiol Dis. 2015;84:109-19. 
5. Casalino E, Calzaretti G, Sblano C, Landriscina V, Tecce MF, Landriscina C. Antioxidant effect of hydroxytyrosol (DPE) and Mn2 + in liver of cadmium-intoxicated rats. Comp Biochem Physiol C: Toxicol Pharmacol. 2002;133:625-32.

6. Dimitrios B. Sources of natural phenolic antioxidants. Trends Food Sci Tech. 2006;17:505-12.

7. Dziekońska A, Świąder K, Koziorowska-Gilun M, Mietelska K, Kordan W. Effect of boar ejaculate fraction, extender type and time of storage on quality of spermatozoa. Pol J Vet Sci. 2017;20:77-84.

8. Feitsma H. Artificial insemination in pigs, research and developments in The Netherlands, a review. Acta Sci Vet. 2009;37:s61-71.

9. Feng J, Yee R, Zhang S, Tian L, Shi W, Zhang WH, Zhang Y. A rapid growth - independent antibiotic resistance Detection Test by SYBR Green / Propidium iodide Viability assay. Front Med-Lausanne. 2018;5:127-31.

10. Gadea J, Selles E, Marco MA, Matás PCC, Romar R, Ruiz S. Decrease in glutathione content in boar sperm after cryopreservation-effect of the addition of reduced glutathione to the freezing and thawing extenders. Theriogenology. 2004;62:690-701.

11. Haugan T, Gaustad AH, Reksen O, Gröhn YT, Hofmo PO. Fertility results of artificial inseminations performed with liquid boar semen stored in X-CellTM vs BTS extender. Reprod Domest Anim. 2007;42:94-9.

12. He Y, Li D, Zhang W, Tian X, Pang W, Du R, Yang G, Yu T. Boar sperm quality and oxidative status as affected by rosmarinic acid at $17^{\circ} \mathrm{C}$. Trop Anim Health Pro. 2020;52:1-9.

13. Jäkel H, Scheinpflug K, Mühldorfer K, Gianluppi R, Lucca MS, Mellagi APG, Bortolozzo F, Waberski P. D. In vitro performance and in vivo fertility of antibiotic-free preserved boar semen stored at $5^{\circ} \mathrm{C} . \mathrm{J}$ Anim Sci Biotechno. 2020;12:1-12.

14. Jiang ZL, Li QW, Hu JH, Li WY, Zhao HW, Zhang SS. Improvement of the quality of boar cryopreservation semen by supplementing with low density lipoprotein in diluents. Cryobiology. 2007; 54:301-4.

15. Jovičić M, Chmelíková E. Markéta Sedmíková. Cryopreservation of boar semen. Czech Journal of Animal Science. 2020;65:115-23.

16. Kedechi S, Zribi N, Louati N, Menif H, Sellami A, Lassoued S, Ben Mansour R, Keskes L, Rebai T. Chakroun, N. Antioxidant effect of hydroxytyrosol on human sperm quality during in vitro incubation. Andrologia. 2017;49:e12595.

17. Kim S, Lee YJ, Kim YJ. Changes in sperm membrane and ROS following cryopreservation of liquid boar semen stored at $15^{\circ} \mathrm{C}$. Anim Reprod Sci. 2011;124:118-24.

18. Knox RV. Artificial insemination in pigs today. Theriogenology. 2016;85:83-93.

19. Krishnappa B, Srivastava SK, Kumar D, Ghosh SK, Kalyan DE, Paul RK, Naqvi SM. K. Effect of hydroxytyrosol on sperm post-thaw motion and velocity of cryopreserved ram semen. Indian J Small Ruminants (The). 2018;24:75-9. 
20. Lane M, McPherson NO, Fullston T, Spillane M, Sandeman L, Kang WX, Zander-Fox DL. Oxidative stress in mouse sperm impairs embryo development, fetal growth and alters adiposity and glucose regulation in female offspring. Plos One. 2014;9:7.

21. Parveen A, Akash MSH, Rehman K, Kyunn WW. 2016. Recent investigations for discovery of natural antioxidants: a comprehensive review. Crit Rev Eukar Gene. 2016; 26: 143-160.

22. Pezo F, Romero F, Zambrano F, Sanchez RS. Preservation of boar semen: An update. Reprod Domest Anim. 2019;54:423-34.

23. Robles-Almazan M, Pulido-Moran M, Moreno-Fernandez J, Ramirez-Tortosa C, Rodriguez-Garcia C, Quiles JL, Ramirez-Tortosa M. Hydroxytyrosol: Bioavailability, toxicity, and clinical applications. Food Res Int. 2018;105:654-67.

24. Park SH. C K. Antioxidative effects of magnetized extender containing bovine serum albumin on sperm oxidative stress during long-term liquid preservation of boar semen. Bioche Biophys Res Commun. 2015;464:467-72.

25. Serreli G, Incani A, Atzeri A, Angioni A, Campus M, Cauli E, Zurru R, Deiana M. Antioxidant Effect of Natural Table Olives Phenolic Extract Against Oxidative Stress and Membrane Damage in EnterocyteLike Cells. J Food Sci. 2017;82:380-5.

26. Simonenko EY, Garmaeva SB, Yakovenko SA, Grigorieva AA, Tverdislov VA, Mironova AG, Aprishko VP. The influence of the storage temperature and cryopreservation conditions on the extent of human sperm DNA fragmentation. Biophysics. 2016;61:267-70.

27. Sutovsky P. New Approaches to Boar Semen Evaluation, Processing and Improvement. Reprod Domest Anim. 2015;50:11-9.

28. Tesi M, Sabatini C, Vannozzi I, Di Petta G, Panzani D, Camillo F, Rota A. Variables affecting semen quality and its relation to fertility in the dog: A retrospective study. Theriogenology. 2018;118:34-9.

29. Tian X, Li D, He Y, Zhang W, He H, Du R, Pang W, Yang G, Yu T. Supplementation of salvianic acid A to boar semen extender to improve seminal quality and antioxidant capacity. Anim Sci J. 2019;90:9.

30. Wang S, Sun M, Wang N, Yang K, Guo H, Wang J, Zhang Y, Yue S, Zhou J. Effects of L-glutamine on boar sperm quality during liquid storage at $17^{\circ} \mathrm{C}$. Anim Reprod Sci. 2018;191:76-84.

31. Watson PF. The causes of reduced fertility with cryopreserved semen. Anim Reprod Sci. 2000;60:481-92.

32. Yeste M. State-of-the-art of boar sperm preservation in liquid and frozen state. Anim Reprod. 2017;141:69-81.

33. Zrelli H, Matsuoka M, Kitazaki S, Araki M, Kusunoki M, Zarrouk M, Miyazaki H. Hydroxytyrosol induces proliferation and cytoprotection against oxidative injury in vascular endothelial cells: Role of Nrf2 activation and HO-1 induction. J Agr Food Chem. 2011;59:4473-82.

\section{Tables}


Table1 Sperm ROS content during storage after adding different concentrations of hydroxytyrosol in sperm dilution. Fluorescence intensity (MFI) was detected at Day $(0,1,3,5)$ (Note: The same letter indicates $P>0.05$, and different letters indicate $P<0.05$ ).

\begin{tabular}{|c|c|c|c|c|c|c|}
\hline Color & Group Name & Counts & Day 0 & Day 1 & Day 3 & Day 5 \\
\hline$\square$ & NC & $9566 \pm 2.51^{\mathrm{a}}$ & $1264 \pm 2.08^{\mathrm{a}}$ & $\begin{array}{c}1915^{ \pm} \\
3.41^{\mathrm{a}}\end{array}$ & $3423 \pm 2.33^{\mathrm{a}}$ & $7047 \pm 3.02^{\mathrm{a}}$ \\
\hline$\square$ & HT $40 \mu \mathrm{M}$ & $9516 \pm 7.04^{\mathrm{a}}$ & $1247 \pm 2.51^{\mathrm{a}}$ & $\begin{array}{c}1888^{\mathrm{a}} \\
1.97^{\mathrm{a}}\end{array}$ & $2598 \pm 6.21^{\mathrm{b}}$ & $5690 \pm 4.04^{\mathrm{b}}$ \\
\hline$\square$ & HT $80 \mu \mathrm{M}$ & $9547 \pm 2.07^{\mathrm{a}}$ & $1270 \pm 6.02^{\mathrm{a}}$ & $\begin{array}{c}1839 \pm \\
5.02^{\mathrm{a}}\end{array}$ & $2547 \pm 5.98^{\mathrm{b}}$ & $5925 \pm 5.56^{\mathrm{b}}$ \\
\hline$\square$ & HT $120 \mu \mathrm{M}$ & $9549 \pm 1.53^{\mathrm{a}}$ & $1233 \pm 3.21^{\mathrm{a}}$ & $\begin{array}{c}1620 \pm \\
3.18^{\mathrm{b}}\end{array}$ & $2001 \pm 2.04^{\mathrm{c}}$ & $4403 \pm 6.03^{\mathrm{c}}$ \\
\hline$\square$ & HT $160 \mu \mathrm{M}$ & $9581 \pm 10.09^{\mathrm{a}}$ & $1273 \pm 0.57^{\mathrm{a}}$ & $\begin{array}{c}1890 \pm \\
4.85^{\mathrm{a}}\end{array}$ & $2501 \pm 1.98^{\mathrm{b}}$ & $6541 \pm 8.12^{\mathrm{ab}}$ \\
\hline$\square$ & HT $200 \mu \mathrm{M}$ & $9516 \pm 7.76^{\mathrm{a}}$ & $1295 \pm 6.08^{\mathrm{a}}$ & $\begin{array}{c}1889 \pm \\
2.73^{\mathrm{a}}\end{array}$ & $2509 \pm 10.5^{\mathrm{b}}$ & $6543 \pm 6.21^{\mathrm{ab}}$ \\
\hline
\end{tabular}

Table2 The results of artificial insemination in pigs. NC means control group ( $0 \mu \mathrm{mol}$ hydroxytyrosol), HT means treatment group (adding $120 \mu \mathrm{mol}$ hydroxytyrosol) (Note: The same letter indicates $P>0.05$, and different letters indicate $P<0.05$ ).

\begin{tabular}{|llll|}
\hline Group & NC & HT & $P$-Value \\
\hline Pregnancy rate (\%) & $76.70 \pm 1.00^{\mathrm{B}}$ & $89.30 \pm 2.00^{\mathrm{A}}$ & 0.0041 \\
\hline Laying births & $12.73 \pm 2.18^{\mathrm{a}}$ & $12.64 \pm 1.93^{\mathrm{a}}$ & 0.5312 \\
\hline Live number & $11.52 \pm 1.88^{\mathrm{a}}$ & $11.73 \pm 0.98^{\mathrm{a}}$ & 0.4937 \\
\hline Live rate (\%) & $90.09 \pm 1.32^{\mathrm{a}}$ & $90.61 \pm 0.61^{\mathrm{a}}$ & 0.0965 \\
\hline Healthy number & $10.37 \pm 0.62^{\mathrm{a}}$ & $10.91 \pm 0.39^{\mathrm{a}}$ & 0.1610 \\
\hline Health rate (\%) & $88.83 \pm 0.82^{\mathrm{a}}$ & $91.57 \pm 0.67^{\mathrm{a}}$ & 0.0956 \\
\hline Primary weight $(\mathrm{kg})$ & $1.03 \pm 0.32^{\mathrm{b}}$ & $1.21 \pm 0.36^{\mathrm{a}}$ & 0.0413 \\
\hline
\end{tabular}

\section{Figures}




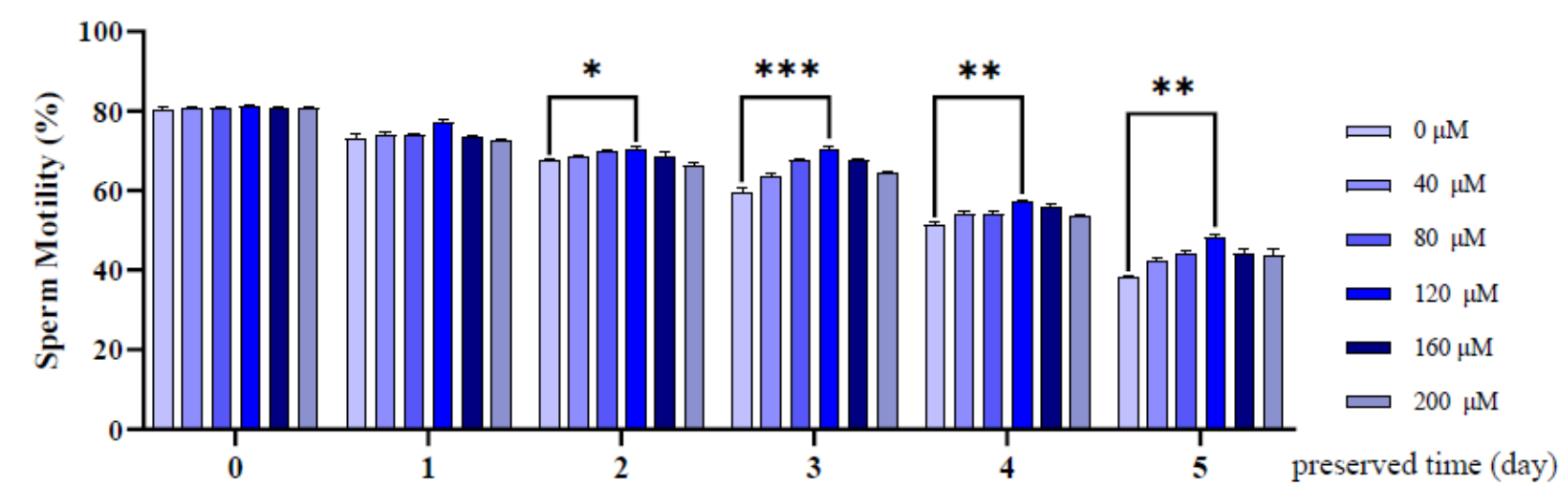

b
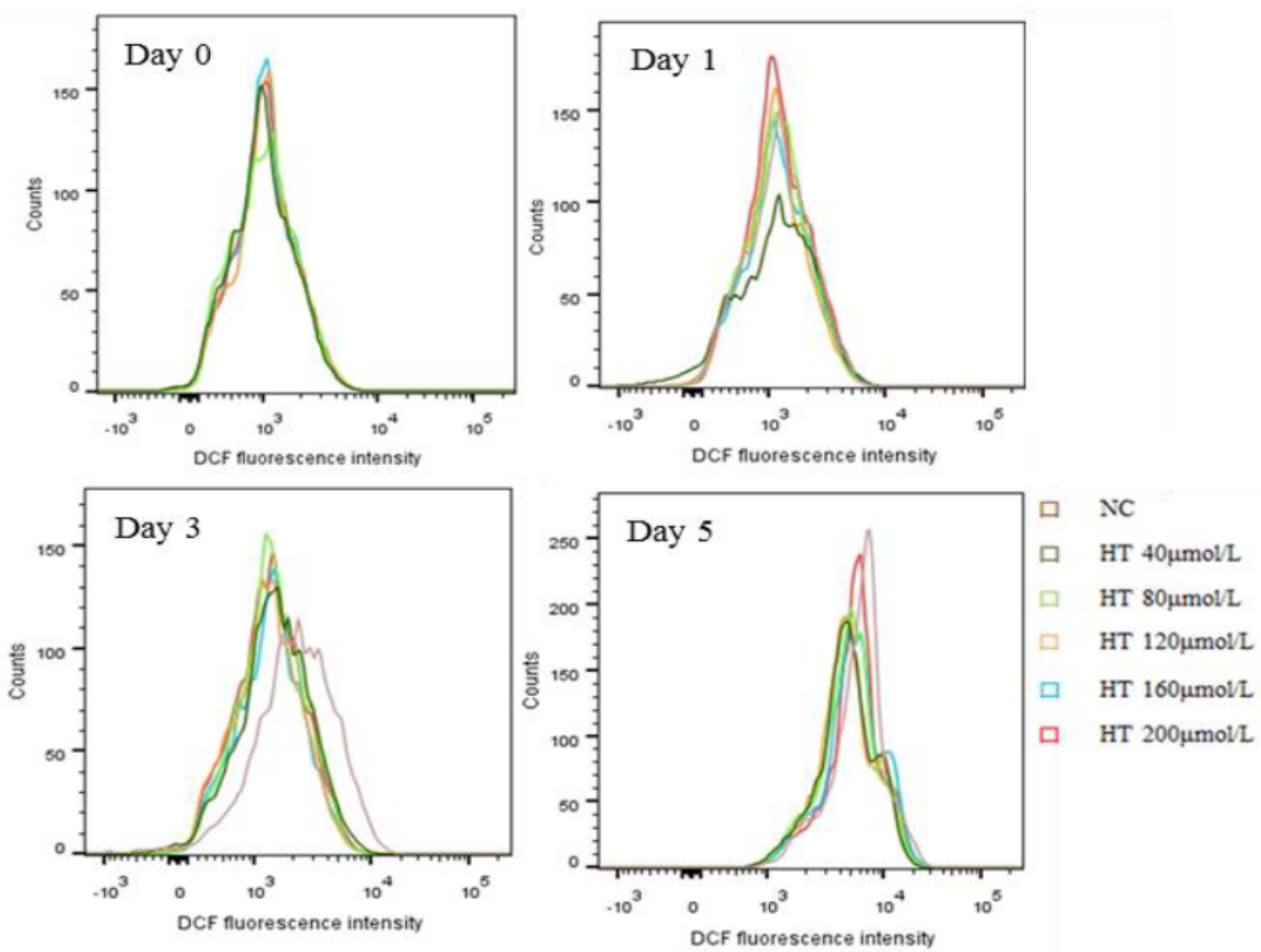

\section{Figure 1}

Hydroxytyrosol improves the preservation of pig sperm at $17^{\circ} \mathrm{C}$. a. Effect of adding different concentrations of HT on the sperm motility of pigs (Note: * indicates $P<0.05$, ** indicates $P<0.01$, *** indicates $\mathrm{P}<0.001$; Sperm motility: the percentage of sperm with forward progressions in total sperm). $\mathrm{b}$. Fluorescence intensity of DCF in each test group at different storage times. 
包 100

b

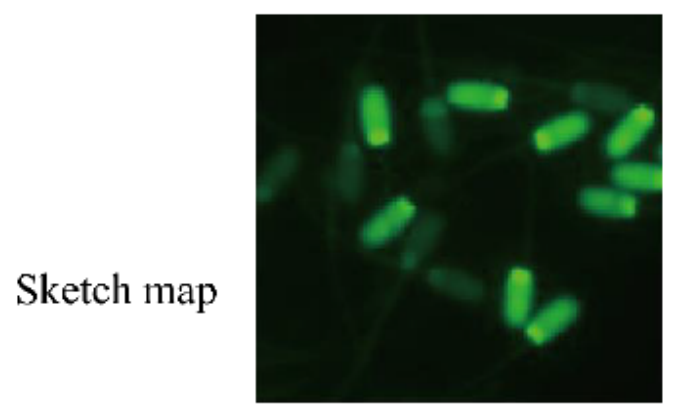

SYBR-14

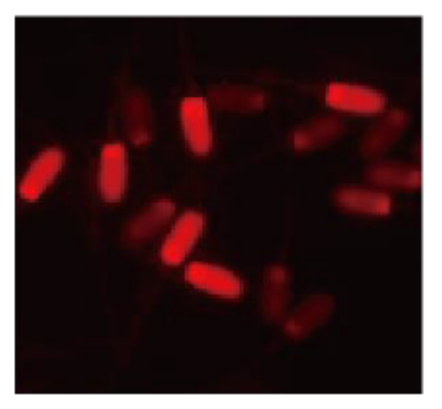

PI

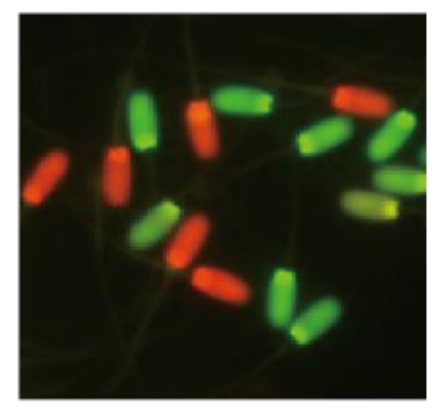

Merge

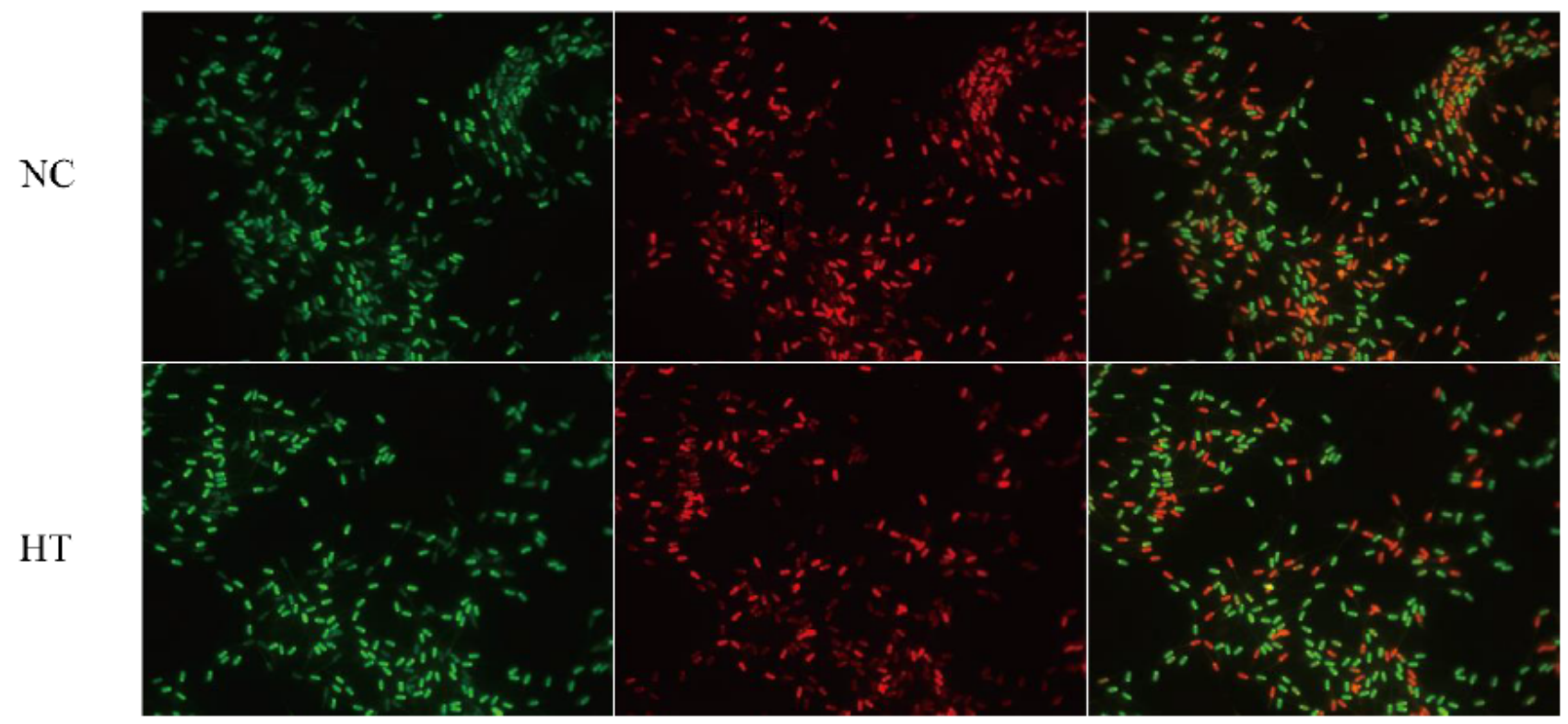

\section{Figure 2}

a. Effect of different concentrations of hydroxytyrosol on sperm plasma membrane in sperm dilution (Note: sperm plasma membrane integrity refers to the percentage of spermatozoa with an intact plasma

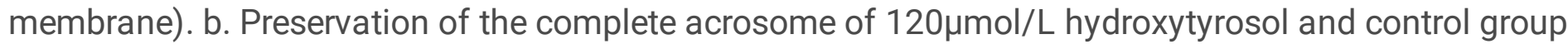
on Day 3 (Note: SYBR-14 green fluorescent labeled spermatozoa with intact plasma membrane, PI red fluorescent labeled spermatozoa damaged by plasma membrane) (Scale: $50 \mu \mathrm{m})$. c. Effect of adding 
different concentrations of hydroxytyrosol in sperm dilution on the integrity of pig sperm acrosome (Note: acrosome integrity refers to the percentage of spermatozoa with an intact acrosome). d. Preservation of the complete acrosome of $120 \mu \mathrm{mol} / \mathrm{L}$ hydroxytyrosol and control group on Day 3 (Note: DAPI blue fluorescent labeled spermatozoa with nucleus, FITC-PNA green fluorescent labeled spermatozoa with

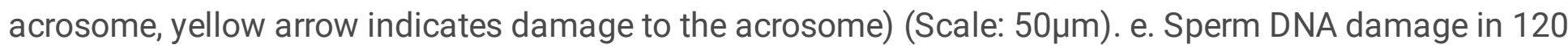
$\mu \mathrm{mol} / \mathrm{L}$ hydroxytyrosol and control group when sperm was stored in Day 3. Note: The same letter indicates $P>0.05$, different letters indicate $P<0.05$.

a

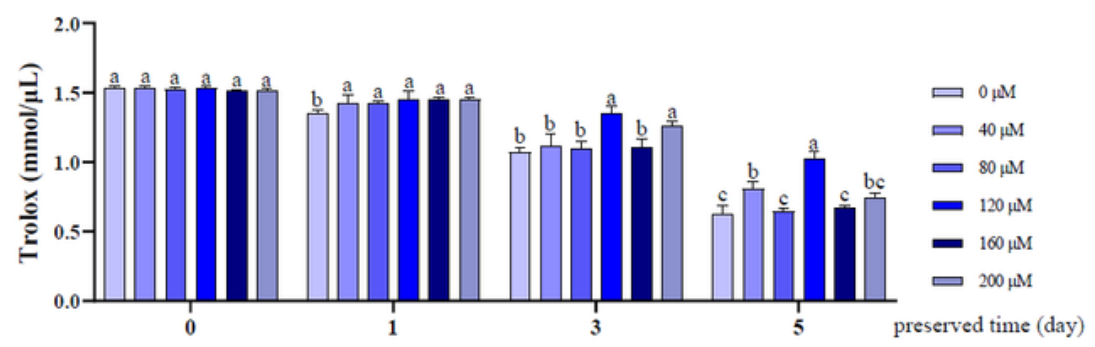

$\mathrm{b}$

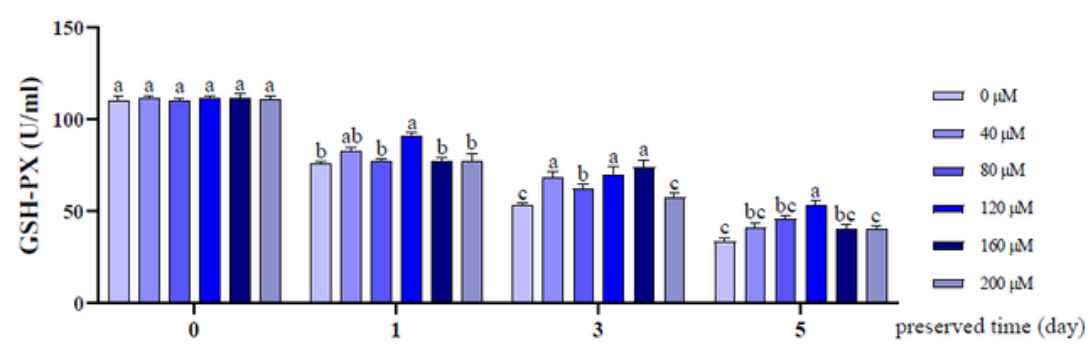

$\mathrm{c}$

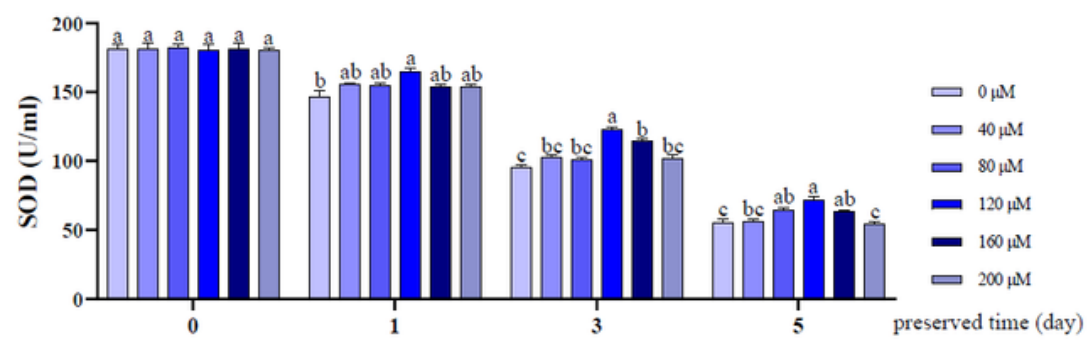

d

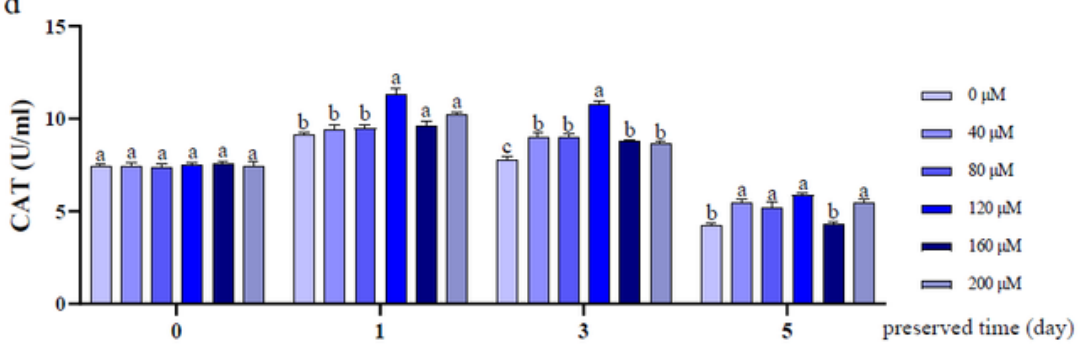

e

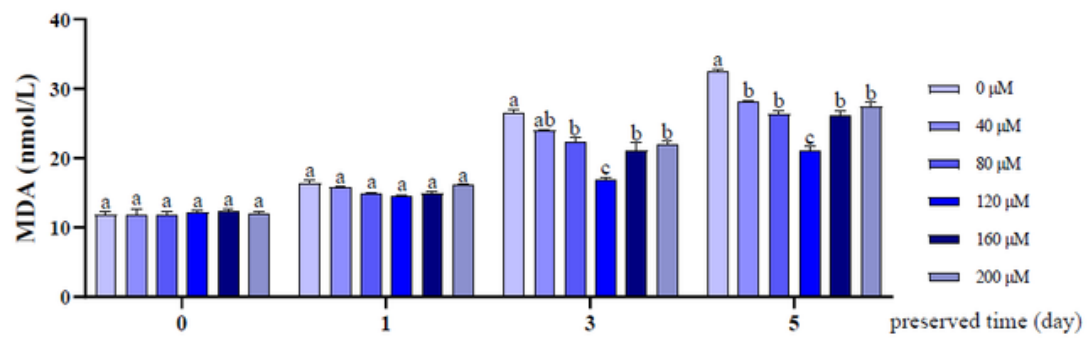




\section{Figure 3}

Hydroxytyrosol slows the rate of decline in sperm antioxidant enzyme activity. a. Effect of adding different concentrations of hydroxytyrosol on total antioxidant capacity of pig sperm. b. Effect of different concentrations of hydroxytyrosol on glutathione peroxidase in pig sperm. c. Effect of different concentrations of hydroxytyrosol on pig sperm superoxide dismutase. d. Effect of adding different concentrations of hydroxytyrosol on pig sperm catalase. e. Effect of adding different concentrations of hydroxytyrosol on the accumulation of malondialdehyde in pig sperm. Note: The same letter indicates $\mathrm{P}>$ 0.05 , and different letters indicate $P<0.05$. 
a

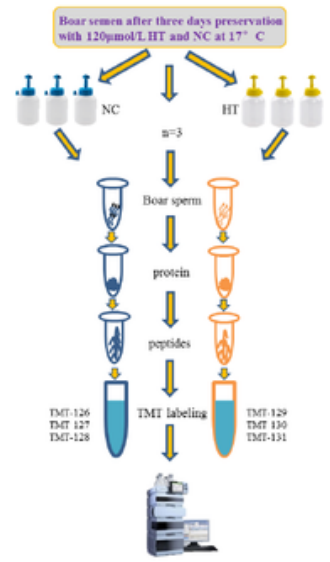

Total spectrums

$\mathrm{n}=\mathbf{2 5 9 8 1 6}$

ป2

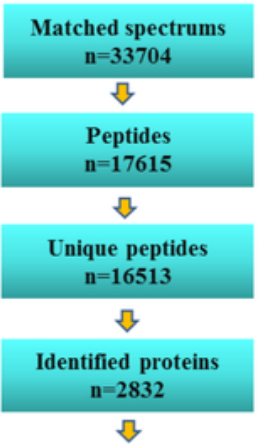

b
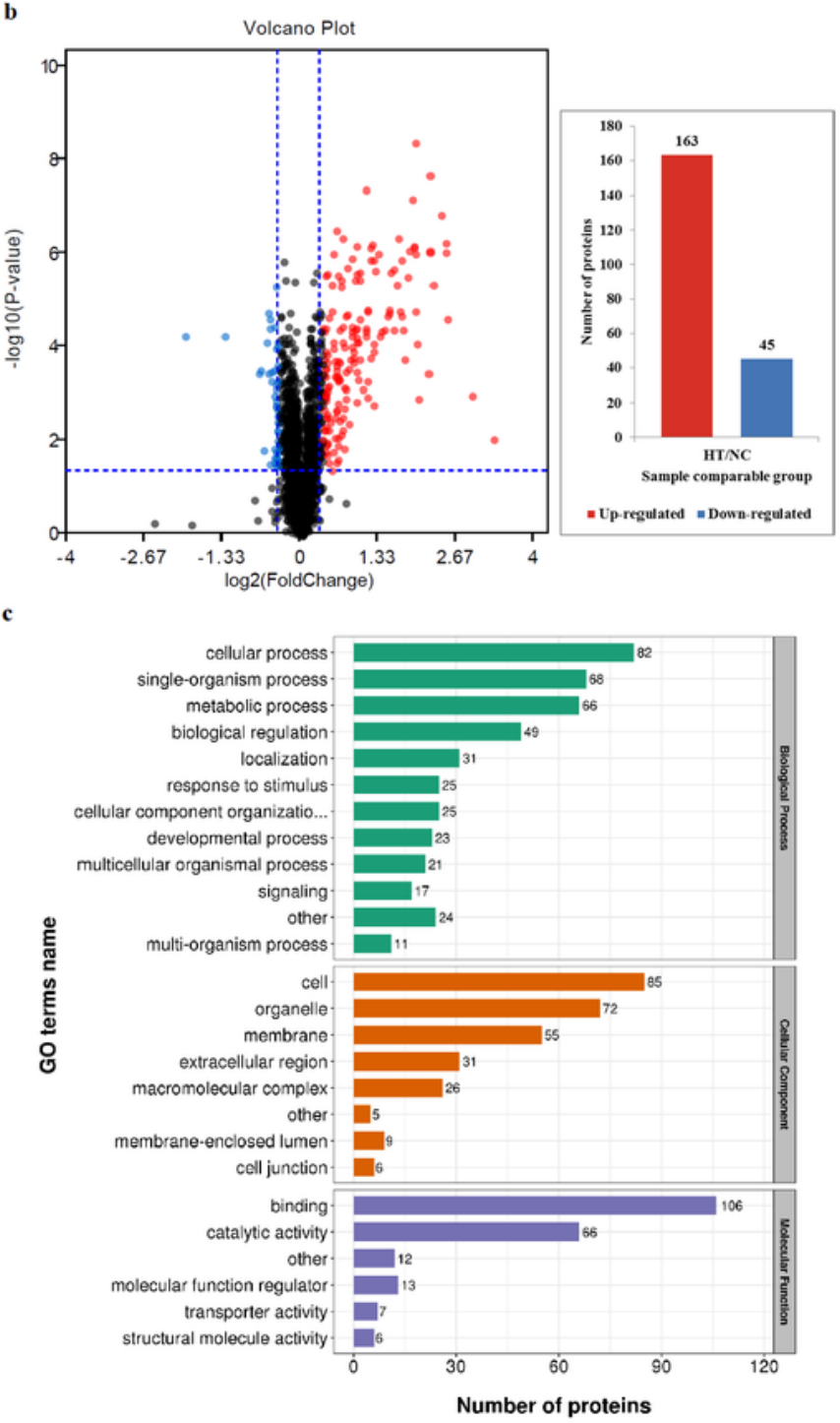

Figure 4

a. Proteomics analysis process and Statistical results of protein mass spectrometry. b. Volcanic map of differentially expressed protein expression in HT/NC. c. Statistical distribution chart of Differentially expressed proteins under each GO category (2nd Level). d. Subcellular localization chart of Differentially expressed proteins. e. COG/KOG functional classification chart of Differentially expressed proteins. 


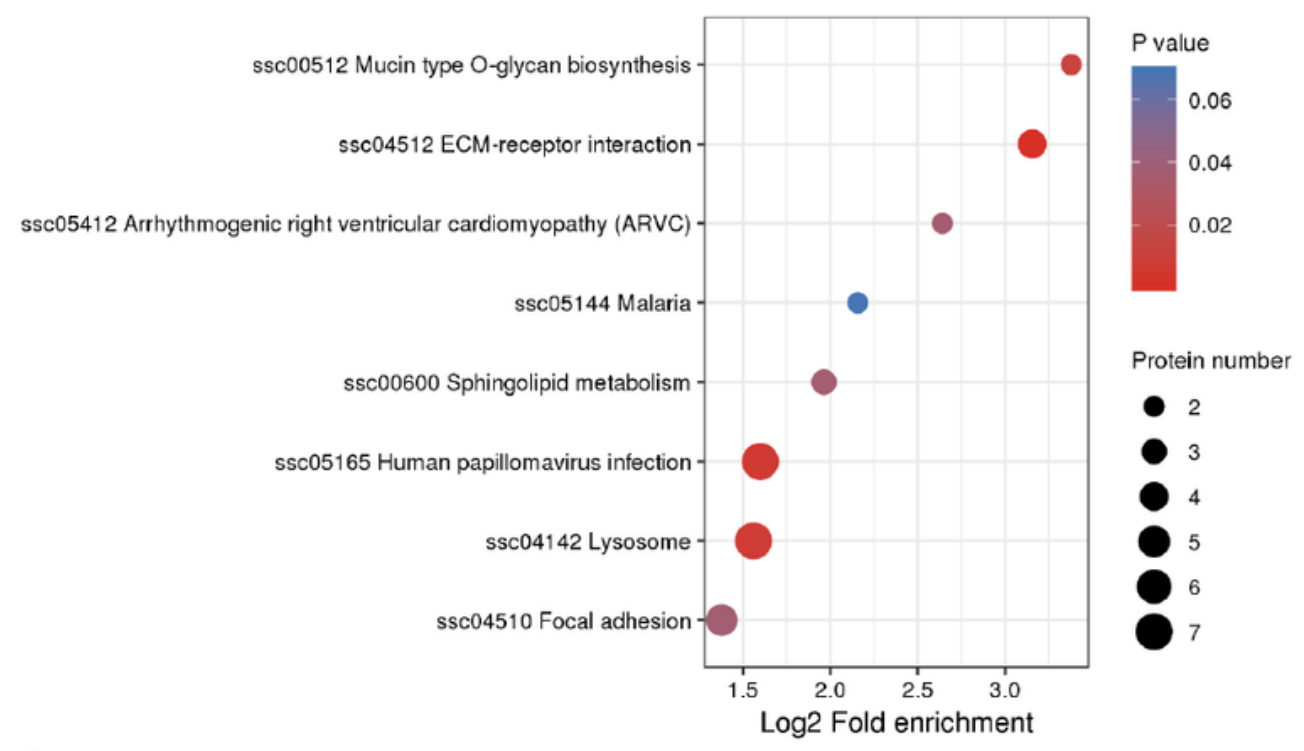

b

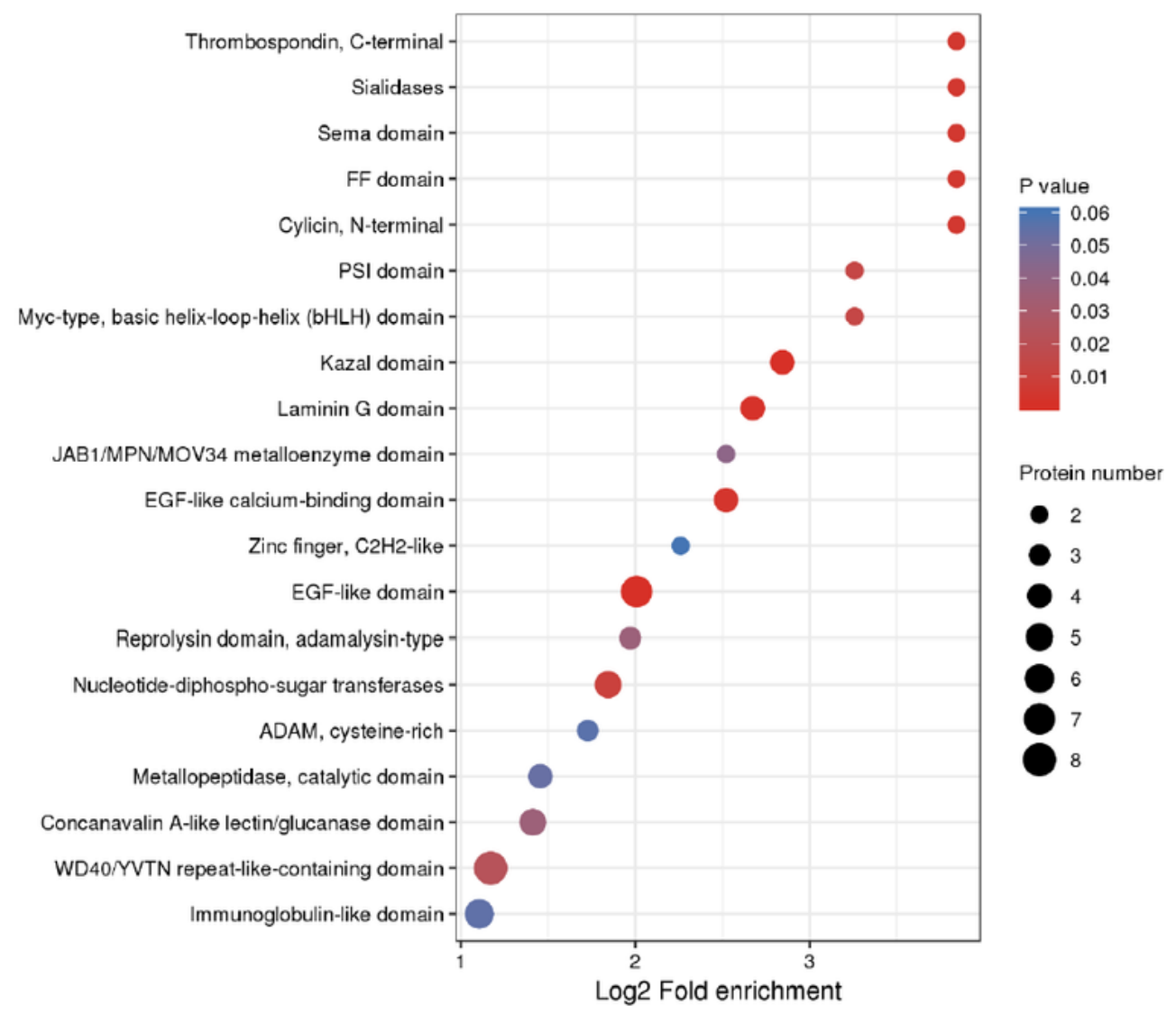

\section{Figure 5}

a. KEGG pathway enrichment bubble plot of Differentially expressed proteins. b. Protein domain enrichment bubble plot of Differentially expressed proteins. The bubble chart gives the results of the top 20 classifications with the most significant enrichment. In the bubble chart, the vertical axis is the functional classification or pathway, and the horizontal axis value is the log2 converted value of the fold change of the proportion of the difference protein in the function type compared with the proportion of 
the identified protein. The color of the circle indicates the enrichment significance P-value, and the size of the circle indicates the number of differential proteins in functional classes or pathways.
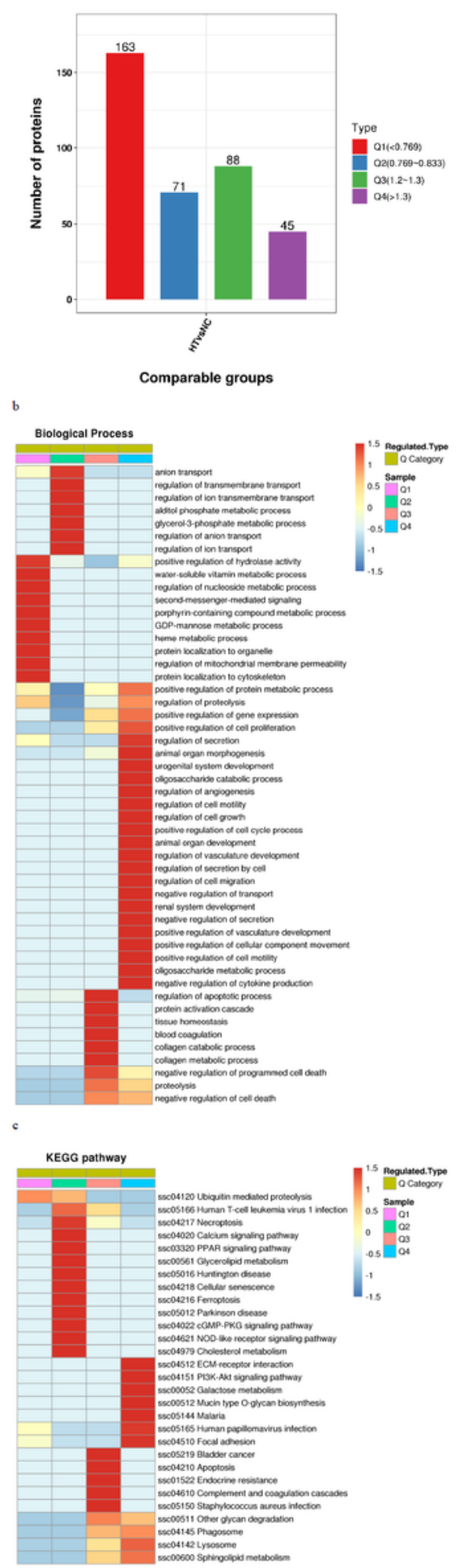

Figure 6

For the differentially expressed proteins, we divided them into 4 parts according to their differential expression multiples, called Q1 to Q4. According to the P value of enrichment analysis (Fisher's exact test) obtained by enrichment analysis, hierarchical clustering method is used to group related functions in 
different groups together and draw as a heatmap. The horizontal direction of the heat map represents the enrichment test results of different groups, and the vertical direction describes the functions of differential expression enrichment (GO, KEGG pathway, protein domain). The color blocks corresponding to the differentially expressed proteins and function descriptions of different groups indicate the degree of enrichment. Red represents a strong degree of enrichment, and blue represents a weak degree of enrichment. a. The difference protein is divided into Q1-Q4 number distribution according to the multiple. b. Comprehensive heatmap for cluster analysis of the enrichment patterns of GO functional categories (Biological process). c. Comprehensive heatmap for cluster analysis of the enrichment patterns of KEGG pathways.

\section{Supplementary Files}

This is a list of supplementary files associated with this preprint. Click to download.

- supplementfigurelegends.docx

- supplementfigure1.docx

- supplementfigure2.docx

- supplementfigure3.docx

- supplementfigure4.docx

- supplementfigure5.docx

- supplementfigure6.docx 